\title{
Adolescent attitudes about altruistic suicide
}

\author{
By Adam Czabanski and David Lester
}

\begin{abstract}
A survey of 1,019 Polish high school students found that some forms of altruistic suicide were viewed favorably, whereas other forms were viewed very negatively. A relatively more negative view in general toward altruistic suicide was associated with being more religious, whereas a relatively more positive view was associated with personal involvement in suicidal behavior and having friends who had committed suicide.
\end{abstract}

It is common, especially in deeply religious countries, for suicide to be considered a sin, and Holyst (2002) noted that this was true in Poland. He said, "Undoubtedly a certain part of the Polish society definitely condemns suicides. These people do not find absolutely any moral justification for suicides no matter what the incidents that made the suicide make an attempt on his or her life." Holyst wondered whether this condemnation of suicide was stronger in Catholics than in those from other religions, in men than in women, and in those who knew individuals who had committed suicide. However, there are exceptions to this condemnation of suicide in cases of altruistic suicide, where individuals die as a result of their own actions in order to save or help others.

Malicka-Gorzelanczyk (2002) surveyed some 700 students, aged 16-20, attending secondary and vocational schools in Bydgoszcz and Gdansk in the late 1990s. Only 9\% of the students viewed suicide positively, and more than half ( $58 \%$ of the girls and $46 \%$ of the boys) felt that potential suicides would be prevented from committing suicide by their religious beliefs. On the whole, the students felt that suicides lacked the courage to face and solve their problems. Malicka-Gorzelanczyk's survey asked about suicide in general and did not present any concrete situations or cases to the students. She also did not focus on altruistic suicide in particular.

Czabanski (1997) surveyed 210 secondary school teenagers from the city of Poznan about their attitudes toward suicide and found that only about one in ten felt that suicide was compatible with their moral principles. However, the older students (18-19 years old) were more accepting of suicide than the younger students (15-16 years old). Boys were more accepting of suicide than were girls. Almost two-thirds of the boys and almost a half of the girls felt that people had the right to commit suicide. When asked in what situations suicide might be acceptable, they mentioned crisis situations, terminal illness, nervous breakdowns, after loss of a significant other, and in times of war. For a person dying from cancer, $43 \%$ of the boys and $26 \%$ of the girls said that suicide was acceptable. After a romantic break-up, only $15 \%$ of the boys and $11 \%$ of the girls found suicide to be acceptable. Czabanski found that $30 \%$ of the boys and $8 \%$ of the girls felt that suicide was acceptable to protest against a totalitarian government. ${ }^{1}$ The present study was designed to explore the attitudes of adolescents toward altruistic suicide, and to explore what personal characteristics and experiences might correlate with these attitudes.

\section{Method}

A questionnaire survey was conducted in March and April 2006 at randomly selected high schools in Poland among last year students who were present on the day that the questionnaire was administered. They gave informed consent, and the project was approved by the University's IRB.

The sample consisted of 1,019 students, 491 men $(48.2 \%)$ and 528 women $(51.8 \%)$. The majority of the students lived in towns with more than 100,000 inhabitants $(51.2 \%)$, followed by villages $(24.5 \%)$. Almost 94\% considered themselves as members of the Roman Catholic Church, followed by $4.2 \%$ of non-believers (atheists). However, only $42.7 \%$ of the respondents took part in religious practices at least once a week. The students were asked how religious they considered themselves, and $9 \%$ rated themselves as very religious, $55 \%$ as religious, $21 \%$ as indifferent but bound to religious traditions, $10 \%$ as indifferent and $5 \%$ as atheists. Regarding personal suicidal experience, the students were asked, "Have you ever tried to commit suicide?" and 61 (6\%) replied yes. In addition, 91 (9\%) had somebody in their family commit suicide in the past, and 132 (13\%) had lost friends who committed suicide.

Each student completed the questionnaire individually in small groups of 10-12 students at a time. They were asked to judge particular examples of altruistic suicides (see Table 1 and 2):

The responses to each scenario were scored as positive (1 point), neutral (0) and negative $(-1)$. Then the scores for the eight scenarios for each student summed to give an overall positive rating score.

\section{Results}

The responses of the students are shown in Table 1 where it be seen that the altruistic suicide viewed most positively was a soldier sacrificing himself to save his comrades, while the altruistic suicide viewed most negatively was a suicide bomber. There were sex differences in the judgments, with five of the eight differences being statistically significant (see Table 2).

The sex difference in the overall rating score was significant (women -2.4 and men -.14, $\mathrm{t}=6.67, \mathrm{df}=1017$, two-tailed $\mathrm{p}<.011)$. Those who had made a prior suicide attempt were less negative $(-1.0$ versus $-2.0, t=3.18, p=.002)$. Having had a family member commit suicide had no impact $(-.20$ versus $-.19, \mathrm{t}=0.35)$, but those with a friend who had committed suicide were less negative (-.20 versus $-1.3, \mathrm{t}=3.12, \mathrm{p}=.002)$.

Religiosity was categorized as very religious $(n=92)$, religious $(n=559)$, indifferent but bonded to religious traditions $(n=216)$, indifferent $(n=100)$ and atheist $(n=52)$. The attitude toward altruistic suicide differed significantly between these groups $(\mathrm{F}=8.78, \mathrm{df}=4,1014, \mathrm{p}$ $<.001)$. The very religious group was most opposed to altruistic suicide (mean score $=-2-54)$, followed by the religious group (mean score $=-2.17$ ), with the atheists least opposed (mean score $=-1.10$ ).

1 The case of Ryszard Siwiec's self-immolation at the Dziesieciolecia Stadium in Warsaw in September 1968, although witnessed by nearly 100,000 spectators, was not widely known in Poland until a film, which glorified this event, appeared in 1999. 
A similar trend from most opposed to least opposed was found for actual religious observances, from "I practice every Sunday and sometimes on working days" to "I do not practice at all." The two largest groups by religion were Catholic $(n=957)$ and atheists $(n=43)$. The Catholics were most opposed to altruistic suicide $(-2.00$ versus $-0.56, t=4.00, d f$ $=998, \mathrm{p}<.001)$.

The size of the home town did not have a significant impact on attitudes toward altruistic suicide $(\mathrm{F}=1.49, \mathrm{df}=3,1015)$.

\section{Discussion}

Overall, these students viewed altruistic suicide negatively, but their opinion differed depending upon the scenario. For a soldier sacrificing himself to save his comrades and for a pilot sacrificing himself to save civilians, the majority of students viewed the altruistic act positively, while for suicide after arrest to avoid betraying comrades more students viewed this positively than negatively. However, for the remaining scenarios, the majority of the students viewed the acts negatively.

As might be expected, the more religious students were more opposed to altruistic suicide in general, and female students were more opposed to altruistic suicide than male students even though several of the scenarios specified a man as the protagonist. It was found also that personal involvement in suicidal behavior and having a friend who had committed suicide (but not a relative) was associated with a less negative attitude toward altruistic suicide.

The negative view of committing suicide so as not to be a burden to one's family was viewed very negatively which is of interest given the theory of Joiner (2005) that perceiving that one is a burden to others is a prominent and common motive in those who commit suicide.

Although this may motivate some suicides, the negative attitudes of these students suggest that it may be rare.

Attitudes toward to this motive for suicide may be strongly dependent on the age of the respondents, and it would be interesting to compare the responses of the elderly to this scenario.

In conclusion, the present study shows that, while Polish students view altruistic in general negatively, some motives for altruistic suicide are viewed positively - committing suicide in order to spare the lives of others (fellow soldiers and innocent civilians).

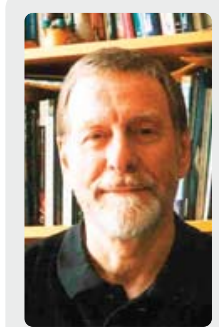

David Lester has doctoral de grees from Cambridge University (UK) in social and political science and Brandeis University (USA) in psychology. He is Distinguished Professor of Psychology at the Richard Stockton College of New Jersey. Lester has published extensively on suicide, murder and other issues in thanatology. His recent books include Katie's Diary: Unlocking the Mystery of a Suicide (2004), Suicide and the Holocaust (2005), Is there Life after Death? (2005) and Understanding Suicide: Closing the Exits Revisited (2009).

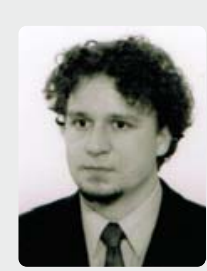

Adam Czabanski, $\mathrm{PhD}$, is suicidologist and medical sociologist at Poznan University of Medical Sciences. He is an author of about 150 publications (including 8 books), concerning health suicidology. Areas of interest: suicidal behaviours of youth, suicides during wars, altruistic suicides, health sociology and social work.

\section{References}

Czabanski A. (1997). Mlodziez wobec samobójstwa. Poznan, Poland: Wydawnictwo Michael.

Holyst B. (2002). Suicydologia. Warszawa, Poland: Wydawnictwo Lexis Nexis.

Joiner, T. E. (2005). Why people die by suicide. Cambridge, MA: Harvard University Press.

Malicka-Gorzelanczyk H. (2002). Opinie mlodziezy o samobójstwie. Bydgoszcz, Poland: Wydawnictwo Akademii Bydgoskiej im. Kazimierza Wielkiego.

\section{Table 1 and 2}

\section{Examples of altruistic suicides}

(1) Suicide of a soldier on a battlefield who throws himself on a grenade to save his comrades from shrapnel

(2) Suicide of a plane's pilot who wishes to avoid crashing on a residential area and crashes his plane earlier onto a nonresidential terrain

(3) Suicide of an arrested conspirator to avoid giving away his companions

(4) Suicide of a kamikaze pilot who intends to kill as many enemy soldiers as possible

(5) Suicide of a poor man (disguised as an accident) who wants his family to get his insurance money

(6) Suicide of an elderly person who does not want to be a burden for his/her family

(7) Self-immolation of a man protesting in this way against social injustice, lack of liberty and religious persecution

(8) Suicide of a man detonating a charge in a public place to terrorize those he considers to be enemies
Table 1: Judgements Table 2: Judgements of

about altruistic suicides altruistic suicides by sex

\begin{tabular}{|c|c|c|c|c|c|c|c|c|c|}
\hline & & & \multirow{2}{*}{\multicolumn{3}{|c|}{ Men }} & \multirow{2}{*}{\multicolumn{3}{|c|}{ Women }} & \multirow[b]{3}{*}{$\begin{array}{l}X^{2} \\
(\mathrm{df}=2)\end{array}$} \\
\hline \multirow[b]{2}{*}{ Positive } & \multirow[b]{2}{*}{ Negative } & \multirow[b]{2}{*}{$\begin{array}{l}\text { No } \\
\text { opinion }\end{array}$} & & & & & & & \\
\hline & & & Positive & Negative & $\begin{array}{l}\text { No } \\
\text { opinion }\end{array}$ & Positive & Negative & $\begin{array}{l}\text { No } \\
\text { opinion }\end{array}$ & \\
\hline 84.1 & 8.2 & 7.7 & 89.0 & 5.7 & 5.3 & 79.5 & 10.6 & 10.0 & $\begin{array}{l}17.02 \\
P<0.001\end{array}$ \\
\hline 82.0 & 6.2 & 11.8 & 86.0 & 4.7 & 9.3 & 78.4 & 7.6 & 14.0 & $\begin{array}{l}9.87 \\
p=0.007\end{array}$ \\
\hline 47.8 & 27.4 & 24.8 & 53.8 & 24.2 & 22.0 & 42.2 & 30.3 & 27.5 & $\begin{array}{l}13.56 \\
p=0.001\end{array}$ \\
\hline 10.6 & 78.0 & 11.4 & 14.3 & 71.4 & 14.3 & 7.2 & 84.1 & 8.7 & $\begin{array}{l}24.01 \\
P<0.001\end{array}$ \\
\hline 9.6 & 73.1 & 17.3 & 11.6 & 70.3 & 18.1 & 7.8 & 75.8 & 16.4 & $\begin{array}{l}5.36 \\
\text { n.s. }\end{array}$ \\
\hline 8.6 & 80.8 & 10.6 & 10.0 & 78.6 & 11.4 & 7.4 & 82.8 & 9.8 & $\begin{array}{l}3.11 \\
\text { n.s. }\end{array}$ \\
\hline 7.1 & 79.2 & 13.7 & 11.4 & 74.8 & 13.8 & 3.0 & 83.3 & 13.7 & $\begin{array}{l}27.64 \\
P<0.001\end{array}$ \\
\hline 2.4 & 92.4 & 5.2 & 2.9 & 91.9 & 5.2 & 2.1 & 92.8 & 5.1 & $\begin{array}{l}0.65 \\
\text { n.s. }\end{array}$ \\
\hline
\end{tabular}

